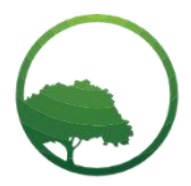

Research in Business \& Social Science

IJRBS VOL 10 NO 7 ISSN: 2147-4478

\title{
The functionality of informal trade in the creation of political power
}

\author{
(D) Oscar Gonzalez Muñoz ${ }^{(a) *(10) \text { Bertha Alicia Arce Castro }}{ }^{(b)}$ \\ (a) Professor, Institute for Research and higher studies of Administrative Sciences, Universidad Veracruzana, México, Av. Dr. Luis Castelazo Ayala \\ S/N, Industrial las Ánimas, 91190 Xalapa-Enríquez \\ (b) Dean Universidad Veracruzana, School of International Business, México, Paseo 112 Lote 2, Nueva Xalapa, 91097 Xalapa-Enríquez, Ver
}

\author{
A R T I C L E IN F O \\ Article history: \\ Received 26 September 2021 \\ Received in rev. form 20 Oct. 2021 \\ Accepted 23 October 2021 \\ Keywords: \\ informal trade, power, illegality, \\ employment. \\ JEL Classification: \\ E26, F59
}

\begin{abstract}
A B S T R A C T
This article delves into the analysis of informal commerce as a means of power created from the street vendor's perspective. This paper aims to evaluate the expressions of the itinerant executors of the practice of informal trade as a means of creating power. To do this, the conception of analysis, using the local practices referring to informal trade, were analyzed as a means of economic sustenance and in the same way, understood among selected groups as illegal. However independent of the local context and the established place. The thesis that follows is that the street trade has a functional character in the obtaining of power by groups; ideological promotion and not just an economic justification. The main findings and results of the research demonstrated that the decisions of the executors of the practice are permeated by a motivation for the illegal practice, which wanders between what is economically necessary and politically permissible. The situation that determines the functionality and applicability of informal trade acts, underestimates compliance with the existence of local trade policies and regulations of social life and instead, they are recognized as legitimate as they belong to groups of political control. Therefore, it contributes to the defense of the hypothesis, based on demonstrating that the practice of ambulance is presented as a valve for attention to unemployment, while it is tolerated as a means of opportunity to the creation of political power independent of the local or regional context.
\end{abstract}

(C) 2021 by the authors. Licensee SSBFNET, Istanbul, Turkey. This article is an open access article distributed under the terms and conditions of the Creative Commons Attribution (CC BY) license (http://creativecommons.org/licenses/by/4.0/).

\section{Introduction}

As a consequence of the state of the Mexican economy and the precariousness of the job market, various investigations related to the informal economy have been carried out. In this sense, the discussion about what is understood by informal economy dates back to 1972. In a study carried out in Kenya, Africa, spoke of many poor workers who produced goods and services "in activities that were not recognized, registered, protected or regulated by public authorities"(Romero, 1972). Meanwhile, other studies such as those by Maza and Santoyo (2016), refer to the atypical situation observed through the transition from the classic traditional occupation paradigm, located in the factory to a heterogeneous and subjective dominated configuration, mainly in services.

In this sense, an element highly mentioned with this practice has been the problem of informal commerce in reference to the term itinerant, to describe commerce practices that operate outside of what is legally permitted (Lezama J., 2018). That is, a connotation protected in the public psyche as an alternative perception to the means of occupation and alternative income, which operates within the framework of what is illegal or not allowed, under the legal perspective of commerce. Meanwhile, its effect on dimensions of understanding the phenomenon as an object of study where factors related to the binding family networks between executors stand out; the economic dimension related to income levels -not audited-; and the social dimension that takes up working conditions, vulnerability, discrimination and work practices in the informal sector and informal employment (Sánchez S. 2018). However, -the precariousness of the labor market-, the political discourse appreciates the discursive opportunity, to the delimitation of the term centered on practices of obtaining and legitimizing power; where the impoverishment derived from economic activity favors de facto power and constitutes a functional means for the realization of the spirit of survival and nature of the State.

* Corresponding author. ORCID ID: 0000-0002-1146-7365

(C) 2021 by the authors. Hosting by SSBFNET. Peer review under responsibility of Center for Strategic Studies in Business and Finance. https://doi.org/10.20525/ijrbs.v10i7.1394 
In this way, within a dialectical exercise between economic growth and employment, this relationship means that regardless of the orthodox of the models versed in development, the informal economy as an exercise is a sequel of structural imbalances associated with the saturation of the demand for jobs; to the value of work, and to the disadvantage of perfect competition. Instabilities that tolerate degrees and different types of involvement in forms of survival, and therefore pose a challenge to the effectiveness of instruments for establishing the public order of life. Based on this, it is necessary to delve into an approach that allows solving methodological conflicts about the relevance of this investigative reference and describe levels of opportunity to study the practice of what is illegal in response to a variant of social exclusion. An approach that is fundamental and decisive, because it justifies the permissibility of illegal practices in the face of various commercial events; thus contributing to the qualitative demonstration of the type of informality practices. Not limited to substitutable employment practice, it involves coincidences of ideological interest between functional groups.

It is in the orbit of the problem related to unemployment and poverty as a resulting condition, where informality is seen as an escape valve for the insertion of the population in economic life, oblivious to the exercise of formal practices. Therefore, the need to assess the importance of its study arises, from the investigative exercise that in the midst of social conditions related to the precariousness of employment; the increase in unemployment and lack of attention to basic needs among Mexicans could contribute to their understanding (CONEVAL, 2020). However, informal trade, here is analyzed from the illegal exercise of the commercialization of products or services that in a conscious and planned way, violates the norms, principles, laws or precepts that regulate commerce in the settlements where it is consumed. This implies an adjustment to the term "itinerant" to describe the practices that functionally allow the executors to normalize a work practice as a means of livelihood in the local context and a response mechanism to the saturation of the labor market. Mechanism that accepts an economic assessment of unemployment and the scope of a permissible means of generating income from an opportunity related to the expected benefits: tax evasion, contractual informality of supplies and de facto powers between groups.

In this research, the term "ambulante" is used to refer to the experience and practices of the ambulantes, without strengthening its interpretation in the ethical sphere of the practice, accused of violating the social roots created and recognized by the company and formal trade in the economy; in whom the assessment of the exercise involves a criminal and accusatory approach to the vulnerability of the rule of law.

\section{Methodology}

The objective of the work is to analyze the expressions of the itinerant executors of the practice of informal trade as a means of creating power. Therefore, it contributes to the defense of the hypothesis, based on demonstrating that the practice of ambulance is presented as a valve for attention to unemployment, while it is tolerated as a means of opportunity to the creation of political power independent of the local or regional context. And evidence, the anchoring between unemployment as a result of market failures and the opportunity for interests of political groups as a result, making the latter part of the political discourse.

However, the evidence in a local context is relevant because it reveals the functional nature of the ambulantaje for the creation of power groups and extends -especially in the study of institutional life-, the maelstrom of vulnerability in which the practice is achieved.

To corroborate the previous hypothesis, a qualitative research was developed -in which semi-structured interviews were applied-, mostly to a non-representative sample of street vendors who expressed their own work experience regarding the exercise of informal work practice. It was explored in the narrative of their experiences and work practices the way in which ambulance -as an economic activity- would have a functional character. For the development of the activity, 2 groups of analysis were formed: 1) street vendors who carry out the exercise as an alternative to an economic activity identified with groups of the National Peasant Workers Confederation (CROC) 2) street vendors who do not have identification with power groups or organization.

In this case, it is important to highlight a methodological reference, such as the study that was carried out under the theoretical and qualitative perspective explained in this work, by the researcher and the executors, who allow arguing that the study is relevant for a particular analysis that entails to the determination of problems not considered in the generality of some studies. The set of information corresponding to the life dynamics of street vendors was obtained through a qualitative study that highlighted the ethnographic method, applying semi-structured interviews with discourse analysis to a certain extent, to a non-representative sample of 181 people, men and women (based in the City of Xalapa and the City of Veracruz between January 14 and March 2, 2020).

Questions and brief questionnaires were prepared that sought to show two observations. The first is related to the alternative of itinerant work as a means of generating income in response to individual economic problems and the precariousness of the labor market. In the second section, we sought to obtain information by means of explanatory variables of informal trade as an individual opportunity in a flexible environment for practice; activity permissible by the local government and creator of groups with de facto political capital. In view of which, the possible experience of being an itinerant merchant as a generator of non-economic benefits was investigated. 
Based on the above, this work is divided into three main sections. In the first one, relevant theoretical arguments are used to analyze itinerant practice as part of informal trade and the justification known as a consequence of market failures and the value attributed to work.

The second section delves into what are the practices, uses and experiences that benefit the practice of informal trade and experiences that make the condition of the street vendor survive. And, the third section, conclusions are proposed that could help to promote a debate on the power groups created outside of the experience.

\section{Theoretical Approaches in the Study of Ambulant Age as a Practice of Informal Trade}

Given the need to address the complex term related to the study of informal trade through an expression such as ambulantaje, it is necessary to consider at least 2 relevant theoretical arguments that relate to this work in the analysis of market failures. The first one is to appreciate the problem of informal trade as a residual problem of employment and occupation; escape valve to the need for income. And therefore, an alternative of occupation of the public space as the establishment of the market, in a relationship dependent on alternative supply of products with a current demand level that makes it a permanent activity. Second, there is the argument focused on informal trade as a product of an economic structure that is strengthened as a result of institutional weakness, where the set of established norms accept and tolerate its practice.

However, it is not only in institutional weakness that tacit deficiencies are recognized. In the form of the organization and typology of the informal market, the political interest of the institutions in the environment is perceived, which strengthen and give evidence of the motivations for the exercise of this type of trade. Especially where informal practice coincides with historical conventional practices as a means of acceptance versed in uses and customs of institutional tolerance.

In this case, there are local means of verification that, in the case of Mexico, evidence the thesis that informal trade is the result of a power-claiming process that accepts it and makes it functional to the market. The existence of public actions and policies incline informal market participants to opt for informality to varying degrees, finding incentives to enter voluntarily (Perry, Maloney, et al., 2007).

Understanding the informal economy as a normal phenomenon accentuates the debate of the spheres and political interest that precedes it and that ends up perceiving it as normal to an urban phenomenon, a consequence of the high rates of rural-urban migration, of the structural adjustment programs of the Tokman decades (2004); the decline in rural productivity and development promotion schemes, attributing the importance of addressing it through investment in physical capital and technological progress; in line with what Adam Smith in the eighteenth century, recognized as acquired and useful productive faculties of all the inhabitants of a country as means of development (Brunner and Elacqua, 2003).

The work entitled "Resolution and Conclusions on decent work and the informal economy" stands out, adopted on June 19, 2002, of the International Labor Conference, which shows as part of the results that the improvement of the skills of workers in the The informal economy is key to increasing their ability to access paid jobs, improve productivity and increase income, and for this, access to education and skills development services must be promoted and democratized. However, the ILO recognizes that workers in the informal economy can hardly dedicate time to training, and that available training may be supply-oriented and not respond to real opportunities to create livelihoods. The most successful experiences combine the acquisition and improvement of skills with the practice of activities related to production and income generation within the framework of a broader and multidimensional training for the development of entrepreneurship, such as creation and management of cooperatives and producer associations and access to finance, technology and markets.

In this sense, it should be remembered that informal trade represents an alternative to employment as a means of obtaining income; Also in the middle of this structure, informal companies are organized that attend to unemployment through employability actions without social protection and strengthen the concept of "employment in the informal sector" to the broader concept of "informal employment".

In the case of Mexico, Center for Public Finance Studies. (CEFP, 2017), it is estimated that in the informal sector it has increased over time, the employment rate in the sector has remained relatively stable during the last 20 years (1998-2017) hovering around a level that averages $26.5 \%$ of the employed population in the country. For 2017, the ENOE found that all forms of informal employment totaled 29.7 million people and represented 57.2\% of the employed population. Practically six out of every ten Mexicans (INEGI, 2017). For 2018, there were 30.5 million people and represented 58\% of the employed population (INEGI, 2018). For 2019, there were 30.9 million people and represented $58.2 \%$ of the employed population (INEGI, 2019). By 2020, They were 29.2 million people and represented $57.5 \%$ of the employed population (INEGI, 2020).

However, a measure of attention to informality has been fiscal policy through reforms to the Federal Tax Code. According to Hernández et al (2005), the small taxpayers regime was introduced in 1998 to encourage the informal sector to register with the Ministry of Finance, and especially those entrepreneurs who had obtained income of less than two million pesos in the previous year. Tax rates are applied according to gross income, but in reality they are insignificant, with a maximum of $2.5 \%$ annual gross income tax. However, in this regime, far from incorporating those who are dedicated to the informal sector, those who paid taxes in another more burdensome regime have joined. 
Meanwhile, the existence of other circumstances favor the development of the informal economy and, therefore, should be considered aside from concentrating the collection effort on certain activities of the informal sector such as the demand for retail products, repair services and restaurants., who consider that wages are similar in the formal and informal sectors in these activities, creating competition between the sectors. That is, they show that if wages are higher in the formal sector, workers will get involved under arguments based on rational expectations.

In this sense, the Adams and Lomnitz hypothesis predicts that the expansion of State regulation increases the possibilities of irregular activities being carried out, although it does not determine what their true magnitude and characteristics will be. The degree to which these possibilities become reality depends on two factors: a) the regulatory capacity of the State; and b) the social structure and cultural resources of the population subject to these norms. It is evident that the level of development of informal activities and their characteristics will depend on the capacity of the official organizations to enforce the norms they promulgate. What is not so evident is that, in principle, the power of the State does not depend on the set of rules that it tries to apply but also on a system of conveniences for the creation of power groups Lomnitz (1988).

A logical corollary of this analysis is that the highest level of formal regulation of the economy and the ability to neutralize recalcitrant sectors is achieved at the midpoint, consisting of limited supervision of private enterprise through a competent State apparatus. When trying to cross this boundary, resistance is unavoidable, and the breadth of control sought by the proliferation of norms is reduced.

However, there is empirical evidence showing that the informal economy can be characterized as a civil society response to unwanted interference from the state. The universal nature of the phenomenon reflects the great resistance capacity of most societies to the exercise of state power. That is, in the midst of processes of social articulation, it can be officially declared that a certain activity is illegal without thereby disappearing, given the high concentrations of power, organization and effective results of planning and dialogue among those who make the informal economy a means of survival.

In this sense, the disappearance of an entire economic sector can be legislated and yet it can subsist and flourish underground. The voluminous literature on the informal economy only confirms its universal character. It describes its characteristics and consequences in settings as diverse as Canada, California, the Netherlands, Mexico, Jordan, and South Africa (Smith, 1987; Lozano, 1989; Lomnitz, 1988; Doan, 1992; McKeever, 1998).

The studies of Meagher (1995); Cheng and Gereffi (1994); Díaz (1993), show that the informal economy has positive effects for the State. In less developed countries, where legislation protecting workers is often much more advanced than the ability of the formal economy to ensure full employment, the informal enterprise has a dual role. First, it employs and provides an income to a significant segment of the population that would otherwise be deprived of any means of subsistence. In these countries, the "cushion" constituted by the informal economy can represent the difference between some social tranquility and permanent political upheaval. Second, the goods and services supplied by informal producers reduce the consumption costs of workers who work in the formal economy and the production and distribution costs of formal companies, thus contributing to their viability (Portes, 1997). (Mercado C., Gómez H. 2017)

However, in developing countries and the third world, the low wages earned by formal sector employees are partly offset by their higher purchasing power through the purchase of informally produced goods and services. Large companies can offset the higher costs derived from tax and labor codes by limiting the size of the declared workforce and outsourcing the rest to informal entrepreneurs. With these mechanisms, the informal economy contributes to the political stability and economic viability of the poorest nations. These facts help explain why many governments generally tolerate informal activities in contradiction to their enforcement obligations. Cross (2000); Kempe (1993) y Birbeck (1978).

\section{Informal Trade, Practices and Experiences of Workers}

The initial argument of this work was to obtain information that would allow to delve into the causes of the choice of the itinerant trade practice from the expression of the itinerant; the forms of organization and incorporation into a work scheme; and in most cases, the causes of the practice. That is, to show the economic and non-economic motivator as the cause of the activity.

One aspect that stands out is that the practices assimilated through the trajectory of the informal and frequent trade of the respondents among those who recognize themselves as executors, do not do so under a specific argument of recognition of an illegal practice, which is evident: sale of products of unknown origin and offered for sale in prohibited places; unverified, no warranty from.

From the point of view of the ambulant himself, the type of commerce involves an activity related only to processes of assimilation to the need to obtain income to meet needs in the order of what is necessary to live; including what is related to their space of needs or deficiencies not only food. And it manifests itself in a complex and contrasting income-obtaining structure, articulated even with informal hiring schemes for subordinates and under the recognition of being able to become formal merchants. This shows that informal commerce has an efficient organization stamp well versed in results planning, economic convenience and political structure.

The population under study showed marked features of structured organization in street markets through two main groups: 1) street vendors who carry out the exercise as an alternative to a competent economic activity identified with a power group known in the 
region as the National Confederation Peasant Worker (CROC); 2) itinerant merchants who have no competence to develop another activity and make informal sales their main source of income.

However, apart from this analysis, there were workers without a piecework contract; and informal traders who agree to paid activities with other street vendors. This is because its main income generation scheme is due to the commercialization of the value of work, without an articulation of buying and selling of assets for sale and in a second place, those that through informal trade as the main income-generating activity they erode their survival interests for other justifications. Considering these particularities allowed to establish the characteristics associated with studies on the informal economy.

In the first of the subgroups of study "traveling salesmen who carry out the exercise as an alternative to an economic activity under the tutelage of an organized power group of the National Peasant Workers Confederation (CROC)", it is of special interest to carry out the activity as means of survival and source of flight to unemployment. In this group, the flexibility of the environment for the exercise and the economic deficiencies to practice the practice are recognized. Meanwhile, under this circumstance there is a process related to the permanence of the facility as long as unemployment is present.

The presentation of the street vendor in the middle of the environment where it operates, shows that there are at least some relevant aspects for the analysis of commerce in different environments. Initially, it highlights that the action of making the purchase and subsequent sale of a product, based on the established standards, is not recognized as a priority for promoting the practice of final marketing. It is recognized as a justified exercise to operate informal commerce, and to sell what is considered regulated or not regulated by an authority.

While under the argument of "Obtain what you need to eat", as an exercise assimilated to a market alternative that accepts that a merchant sells what he recognizes as necessary and is convenient for both. In this sense, it highlights that the commercialization exercise is immersed in what is viable, of sale and purchase, regardless of its origin.

However, regardless of the uses that are obtained by being an itinerant merchant, the spectrum of commerce is favored as a selfemployment option for others. In this sense, it is evident that the reproduction of the productive alternative is conceived as a figure of occupation and self-employment among those who exercise it in reference to what others do. It highlights that the exercise of ambulantaje is a replicable and frequently intergenerational activity.

Another dimension of analysis was the hiring and organization of workers. The exercise of the processes of the way of working, is determined by an employer or boss who hires subordinates, entails organizational processes and consolidation of procedures.

In 2020, this unique phenomenon allows us to understand that in the informal economy, the objects of study and related schemes such as informal hiring, show contradictions between being an informal worker with the argument of the precariousness of the labor market, although insufficient to be attended from an instrument aimed at this situation. It stands out that in the case of the precariousness of the labor market, the project of connection related to how I became an itinerant in the middle of a market contextualized as formal is favored, without initially considering the precariousness of the job offer.

In the second subgroup related to those merchants who acknowledge not having identification with a power group and without social shelter, this group recognizes the practice of informal trade as an opportunity dependent on the nature of the good and linked to the market. However, its distinctive feature begins as the precarious socioeconomic condition that the ambulant presents. In this case, the accreditation of the form of illegality is associated with conditions of opportunity of what is sold and is recognized as low value goods. The street vendor, oblivious to group organization schemes such as the CROC, shows little social participation

In this type of subgroups, informal practices are due to a heterogeneous diversification of products for sale and the environment of the product that is consumed takes strength. In relation to it, the place of settlement in the places where the study is carried out stands out. Such is the case of 1) the natives of the city of Xalapa who sell products in the informal market identified with groups of de facto political power and 2) street vendors without identifying the de facto political power. Heterogeneity is helped according to belonging to the power group. While the organization of the sale and its characteristics is considered similar.

\section{Discussion}

Located and studied in the context of the city of Xalapa and the city and port of Veracruz in 2020, street vendors have managed to develop under a spectrum of commerce within the framework of informality as a means of generating income. As regards being considered the only means to generate income, it has a similar situation: it is the only recognized means to generate income, they contribute to the family economy to support children and by not having education beyond the basic they justify the act.

Said characteristics expressed in a conscious way, allow the articulation of forms of organization of the ambulant and individual characteristics that affect its reproduction: a flexible scheme of street and temporary mobility that allows the generation of income in the order of immediate access to the job market; job opportunity in the order of the same practice and finally the transfer of the status of merchant as a source of employment (Crossa N., 2018). However, its de facto justification, a result of the natural conditions of social precariousness 
Both ways of justifying the exercise imply different ways of recognizing and dissuading it in at least two phases. On the one hand, an organizational scheme that obeys an employment policy and, on the other, an educational policy scheme for the development of skills. While an institutional path, it is a priority to erode the political power and group interests turned into interests of political association of street commerce.

The organization scheme and creation of public power quotas, within groups such as the well-known C.R.O.C., leads to the recognition of the practice of informality as an activity of group interests; granted by a power built based on union representation that contributes to the legitimization of the supporters of public power and, in turn, as an identification of the street vendor as an agent of political development (Ortiz Murillo 2018).

In such a case, the organized and formally established company, which is captive to a tax scheme in exchange for certainty and employer-worker commitment, is not valued or frequently known by the informal worker. In other words, a problem associated with the practice of the itinerant company is the risk of recognition of the practice of commerce as an activity protected by the rights of the worker in the formal organization, which is not recognized.

However, the foregoing, some experiences of illegality are not only manifested in the fact of the sale of products, they are also related to other structures related to the ways of doing business. The sale of bale clothing - imported from the United States as waste material to Mexico - deepens a double illegality.

Finally, informal traders highlight social vulnerability as a cause of exercise. And this perception prevails despite perceived capital goods such as late-model cars, smartphones, and defined aesthetic appearances that do not denote poverty turn out to be common stereotypes. Although despite this, not having a fixed place for sale to face changes in weather and possible assaults are a concern in both groups.

In this sense, an important exercise is to corroborate these types of concerns were they maintained in both groups. In general, the informal trader makes the decision to establish himself from an idiosyncratic cost-benefit perspective. Most of them are young people, married and with children motivated by a precarious or precarious socioeconomic structure. They are also recognized as poor and without income other than that necessary for subsistence with limited or no basic education. However, its main motivation is the exercise of buying and selling as a means of generating profit using money.

The main outstanding attribute in the exercise of ambulantation is eminently economic and a response mechanism to the care structure is to recognize the permissibility of those who lead the group structure authorize its establishment and communicate obligations and rights. It would be necessary to deepen what are the permissibility conditions and the rights and obligations. Informal trade is presented as an alternative of change of occupation and a faithful alternative that generates income.

Likewise, its eminently alternative character to unemployment defines the relationship between sufficient income and the characteristics of traders in order to avoid social vulnerability. In short, it is informal who, in the practice of survival, seeks to access income levels in the order of what is permissible by the environment. In this sense, an educational policy for the development of skills and attention to the precarious labor market will hardly be faced or reduced.

\section{Conclusions}

Informal commerce from the street vendor's perspective refers to practices of economic survival in the midst of a social reference and in a flexible system to comply with regulations. However, it would be necessary to deepen the way in which environments strengthen informal market practice; accepts the consumption of products based on certain characteristics and tolerates direct impact on current tax schemes. Therefore, informality under the practice of commerce acquires a dynamic of political attention that favors and justifies its existence.

In this study, it is evidenced that facing risks related to the practice of informality from the legal means, as well as the lack of certainty in the order of institutional processes, is not recognized as deterrent determinants by the practitioners of the trade. Although it highlights that if it is recognized, the association of the terms of formality and the tax obligation scheme.

The integration of the executors of trade into organized groups, as a resource for organizing and responding to a practice of unemployment, demonstrates the independence between legality and value of work focused on informal trade when referring to income-generating practices. The main purpose of the informal merchant is an economic criterion, however, the constant search for economic alternatives locates it and exposes it to new known vulnerabilities, which are strongly supplied by belonging to a group or union, although those that are not part of that group of power, they recognize not to be a determinant of discouragement in practice.

The exercise of informal trade means diversification of processes related to the structure of the market and local practice. Therefore, it is necessary to consider the scope of informality within a framework of sustained integration processes between those who become ambulance providers, as well as those who favor the practice of the practice.

Some of the ideas expressed help to explain the existence of the informal market and the meaning that the merchant achieves for processes and projects of a normative and public policy order. It is convinced that the informal economy and the transgression of 
social and coexistence norms could be part of the attention to the problems related to informality from a post-disciplinary point of view.

In this way, the main contribution of this project is to highlight the immediacy of the practice in the decisions of the vulnerable population, from which significant aspects emanate in the expression of the unions. The formalization of the street vendor as the executor of an illegal act of commerce, involves the redesign of social instruments aimed at the vulnerable population and in the same way, respecting the normative framework of coexistence and equitable social development.

In this sense, a limited aspect in the research work is the approach to the informal economy from temporary schemes that do not favor the development and creation of incentive programs in the midst of processes of contraction or economic crisis.

\section{References}

Adams, R. (1970). Crucifixion by Power. Austin: University of Texas Press.

Birbeck, C. (1978). Garbage, Industry, and the vultures of Cali, Colombia. Casual Work and Poverty in Third World Cities, edited by R. Bromley and C. Gerry. New York: John Wiley.

Brunner, J. and Elacqua, G. (2003). Human Capital Report in Chile -online-. Adolfo Ibáñez University 78 (1) 19-31.

CEFP. (2017). Center for Public Finance Studies. Fiscal impact of the informal economy in Mexico. Work document. Published in https://www.cefp.gob.mx/transp/CEFP-70-41-C-Estudio0011-300718.pdf

Cheng, L. and Gary G. (1994). The Informal Economy in East Asian Development. International Journal of Urban and Regional Research 18 (1), 194-219.

CONEVAL (2014). Short-term economic and social trends, national results. CONEVAL 14 coneval.org.mx/Medicion/Paginas/ITLPIS_resultados_a_nivel_nacional.aspx

Crossa N. (2018). Fighting for a space in Mexico City: Street traders and urban public space, Mexico, El Colegio de México, 18 (1) 336-339. https://doi.org/10.29265/gypp.v29i1.696

Cross, J. (1998). Informal Politics: Street Vendors and the State in Mexico City. Stanford, CA. Stanford University Press.

Doan, R. (1992). Class Differentiation and the Informal Sector in Amman, Jordan. International Journal of Middle East Studies 24 (2), 27-38.

Hernández, F. and Guerrero, J.P. (2005). Taxes in Mexico: Who pays them and how ?, Budget and Public Expenditure Program, CIDE, 05 (1), 12-29.

National Institute of Statistics and Geography, INEGI (2017). Press release 209/16. Results of the national survey of occupation and employment figures during the first quarter of 2017. Retrieved on September 26, 2021. from https://www.inegi.org.mx/temas/empleo/

National Institute of Statistics and Geography, INEGI (2018). Press bulletin 354/18. Results of the national survey of occupation and employment figures during the first quarter of 2018. Retrieved on September 26, 2021. from https://www.inegi.org.mx/contenidos/saladeprensa/boletines/2018/enoe_ie/enoe_ie2018_08.pdf

National Institute of Statistics and Geography, INEGI (2019). Press release 399/19. Results of the national survey of occupation and employment figures during the first quarter of 2019. Retrieved on September 26, 2021. from https://www.inegi.org.mx/contenidos/saladeprensa/boletines/2019/enoe_ie/enoe_ie2019_08.pdf

National Institute of Statistics and Geography, INEGI (2020). Press release 280/21. Results of the national survey of occupation and employment figures during the first quarter of 2020. Retrieved on September 26, 2021. from https://www.inegi.org.mx/contenidos/saladeprensa/boletines/2021/enoe_ie/enoe_ie2021_05.pdf

Kempe, R. (1993). Growth and Impact of the Subterranean Economy. Third World. Futures 1 (10), 864-876.

Lezama, J. (2018). State and itinerant commerce: normative foundations for the regulation of street vendors, CIDE 19 (1) $101-119$.

Lomnitz, L. (1988). Informal Exchange Networks in Formal Systems: A Theoretical Model. American Anthropologist 22 (2) 1-19.

Lozano, B. (1989). The Invisible Work Force: Transforming American Business with Outside and Home-Based Workers. New York: Free Press 24 (4) 475-491.

Maza, C., O. and Santoyo, L. E. (2016). The Mexican labor market, the difficulties of informality. Research and Science of the $\begin{array}{lllll}\text { Autonomous } & \text { University } & \text { of } & \text { 8guascalientes, } & \text { (69), }\end{array}$ http://www.uaa.mx/investigacion/revista/Hemeroteca/REVISTA_69.pdf

McKeever, M. (1998). Reproduced Inequality: Participation and Success in the South African Informal Economy. Social Forces 76 (6), 19-34.

Meagher, K. (1995). Crisis, Informalization, and the Urban Informal Sector in Sub-Saharan Africa. Development and Change 26 (4), $59-72$.

Mercado, G. (2017). Creative industries in the street: street vendors, aesthetics and use of social networks in design bazaars and food trucks in Mexico City. International Magazine. (5), 225-261.

Ortiz, M. (2018). Urban policies and street commerce in the center of Mexico City. Convergencia Revista de Ciencias Sociales, S.l. (5), 119-145.

Perry, G. and Maloney, W. (2007). Informality: Exit and Exclusion, The World Bank, 7 (07) 247-297.

Portes, A. (1997). Neoliberalism and the Sociology of Development: Emerging Trends and Unanticipated Facts "Population and Development Review, 23 (6) 1-29. 
Romero, R. (1972). Informal economy. University of Latin American Workers (UTAL), San Antonio de los Altos. Retrieved on September 26, 2021 from the website www.utal.org/economia9.htm

Sánchez, E. (2018). Between streets and avenues: informal, atypical and precarious workers in northwestern Mexico. Amphora 25 (45) DOI: https://doi.org/10.30854/anf.v25.n45.2018.514

Smith, J. (1987). Measuring the Informal Economy. The Annals of the American Academy of Political and Social Science. 19 (3). $78-91$.

Tokman, V. (2005). A voice on the road. Employment and equity in Latin America: 40 years of search Santiago de Chile. Economic Culture Fund 4 (1) 11-24.

Publisher's Note: SSBFNET stays neutral with regard to jurisdictional claims in published maps and institutional affiliations.

\section{() (1)}

(C) 2021 by the authors. Licensee SSBFNET, Istanbul, Turkey. This article is an open access article distributed under the terms and conditions of the Creative Commons Attribution (CC BY) license (http://creativecommons.org/licenses/by/4.0/).

International Journal of Research in Business and Social Science (2147-4478) by SSBFNET is licensed under a Creative Commons Attribution 4.0 International License. 